Veterinary Research in Mexico by the University of Pennsylvania

A CO-OPERATIVE research affiliation has been established between the School of Veterinary Medicine of the University of Pennsylvania and the Institute of Livestock Research (Institute de Investigaciones) at Palo Alto, near Mexico City, of the Mexican Government, and 18,000 dollars is being supplied by the United States Foreign Operations Administration to support the project. E. R. Squibb and Sons of Mexico, a subsidiary of the Olin Mathieson Chemical Corporation, New York, and E. R. Squibb and Sons, New York, are also participating and will assist in financing the undertaking. Prof. G. W. Rake, research professor of microbiology in the University of Penrisylvania, will direct the research work for the University at Palo Alto; before going to Philadelphia a year ago, he was director of the Squibb Medical Division for four years, and for twelve years previously headed the Microbiology Division of the Squibb Institute for Medical Research. Among the research workers from the Veterinary School in Philadelphia who are to be sent to Palo Alto will be Dr. Carlos Espana, who was born in Mexico and is a graduate of the University of Mexico. The Institute at Palo Alto, which was established in the 1940's mainly for combating foot-and-mouth disease, has four laboratory buildings, one large combination laboratory-administration building and thirty-six isolation units suitable for handling large farm animals; a main liboratory has ken set aside for the Pennsylvanian workers and will be known as the Squibb-Mathieson Laboratory for Veterinary Research of the Ministry of Agriculture and Hus. bandry in Mexico and of the University of Pennsylvania. The first investigations to be made at this Laboratory will be one of the blood disease anaplas mosis, which is an infectious condition of the red corpuscles, and, later, studies will probably be mado of shipping fever and brucellosis. The University of Pennsylvania plans to increase greatly the number of fellowships it offers for postgraduate training and, in particular, in return for the facilities at Palo Alto it will offer places for the training of Mexican voterinary workers and other seientists interested in infectious diseases affecting animals, with especial emphasis on those diseases transmissible to man. In conjunction with these new developments in Mexico, a dedicatory meeting was arranged in Palo Alto on November 17, and at the same time the annual conference of the Associated University of Pennsylvania Clubs was held in Mexico City.

Long Ashton Research Station: Report for 1953

'THE annual report of the Agricultural and Horticultural Research Station, Long Ashton, for 1953 (from the Station at Long Ashton, Bristol; pp. $218+13$ plates ; $1954 ; 15 s$.) is of particular interest: as it records the jubilee celebrations held in July of that year, and includes speeches made by Sir Thomas Dugdale, Lord Bledisloe, Mr. Christopher Norbury and Prof. T. Wallace on that occasion. The special jubilee lecture delivered by Lord Rothschild has already been published in the commemorative volume "Science and Fruit". The research work carried out during the year falls into five main categories: pomology, plant nutrition (including that under the Agricultural Research Council Unit for Micronutrients), plant pathology, cider and fruit juices, and domestic food preservation. Among the numerous subjects under investigation, mention may be made of a survey of perry pears in the West Midlands, carried out in view of the increased interest in this beverage. A number of varieties are described and illustrated, and an attempt has been made to sort out the confusion of synonyms. Spray application problems form the subject of a group of papers. A method is described for use in estimating tho penetration of DDT into plant tissues, and the times, strengths and formulations for DD'T and $\mathrm{BHC}$ given for control of apple and plum aphids and of BHC for apple sawfly. A combined DD' $1-B H C$ emulsion has also been prepared. Field trials have been carried out with airflow mist spraying, a technique aimed at reducing both costs and risk of crop damage. Though the method was successful with DDT and BHC: emulsion against plum and apple aphid and apple sawfly, similar applications of lime sulphur failed to control red spider, woolly aphid or apple scab.

\section{Geophysics in Canada during 1953}

THE first volume of the series "Canadian Geophysical Bulletins", an annual review of activity in geophysical research and applied geophysics, published by the Associate Committee on Geodesy and Geophysics of the National Research Council of Canada, appeared in January 1947 ; the latest volume, Vol. 6, was published in Decerriber 1953, but has only comparatively recently been received here (pp. 73. Ottawa: National Research Council of Canada, 1953). It includes a bibliography of papers published during the year under review, either by Canadian workers in the ficld or by scientists from other countries, relating to Canadian problems. Short descriptions are given of nine papers on geodesy (including gravity), forty-two on seismology and the physies of the earth's interior, twelve on meteorology and hydrology, forty-nine on terrestrial magnetism and atmospheric electricity, and forty-two papers on oceanography. In December 1953, thirty-eight companies were known to be operating a total of about a hundred and fifty seismic prospecting parties in British Columbia, Alberta, Saskatchewan and Manitoba. Noteworthy is the publication by W. C. Gussow of the detailed geological, seismic and gravimetric studies of New Brunswick which were conducted for the Shell Oil Company (Bull. Amer. Assoc. Pet. Geol., 37, 1713 ; 1953).

Catalogue of Polish Scientific Literature, 1945-49

VoL. 21 of the "Catalogue of Polish Scientific: Literature" (pp. 441. Krakow : Polska Akademii Nauk) covers the years $1945-49$ and bears the date of publication 1952, though it has only recently been received. It is the first to appear since that for the years 1931-34, but Vol. 20, covering the years 193539 , will be published later. The entries are given alphabetically by authors in eleven main sections-mathematics, physics, astronomy, terrestrial sciences, botany, microbiology, zoology, archæology, geography, technology-with a miscellaneous section, and some sub-sections such as chemical technology. There is also an author index and a list of Polish periodicals from which entries are taken, with the abbreviations used, and which includes 254 items.

\section{Science Masters' Association : Meeting in New- castle upon Tyne}

THE annual meeting of the Science Masters' Association will be held in King's College, Newcastle upon 